\title{
Stormagternes tøven i Centralasien
}

\section{Vibeke Sperling}

Sommerens vold i Kirgisistan viste Centralasiens nye virkelighed: USA og Kina holder sig tilbage og Rusland tøver, for første gang ikke af frygt for de store, men for de regionale magter

Dramaet i det lille centralasiatiske land Kirgisistan i juni blev efterfulgt af noget, der lignede ro og en folkeafstemning om en ny forfatning, der forløb forbavsende fredeligt. Men sagen var snarere, at omverdenen og overgangsregeringen i Bisjkek helst ville tro, at roen var genoprettet. Virkeligheden var, at den etniske og politiske vold efter alt at dømme kun holdt pause.

En rapport fra slutningen af august 2010 fra International Crisis Group (ICG) påviser sandsynligheden for ny vold i Kirgisistans sydlige del. Og det stod og står klart, at centralregeringen helt har mistet kontrol med det voldsramte område.

ICG kalder sommerens etniske eksplosion for 'pogromer' - den rette betegnelse, når omkring 2.000 blev dræbt, det store flertal heraf usbekere. ICG maner regeringen til at støtte en international undersøgelse af baggrunden for volden i primært byerne Jalal-Abad og Osj. Samtidig opfordrer ICG det internationale samfund til at gå sammen for at presse regeringen i Bisjkek til reelt at tage fat om voldens rødder.

Regeringen vil helst vende ryggen til det faktum, at volden kan vende tilbage, og fraværet af effektiv international handling øger den sandsynlighed. "Volden har yderligere uddybet kløften imellem etniske kirgisere og usbekere", ifølge Paul Quinn-Judge, direktør for ICG i Centralasien: "Hvis problemet forbliver ignoreret, vil en ny eksplosion kun være et spørgsmål om tid. Og under den næste eksplosion kan ofrene tænkes at søge hjælp hos radikale islamister, og/eller volden kan brede sig til andre etniske grupper - russere, tatarer, uighurer eller dunganer (de to 
sidstnævnte er oprindelige kinesiske folk).

Radikale islamister spillede ingen mærkbar rolle i juni, men det sydlige Kirgisistan rummer islamistiske grupper, som vel kan tænkes at fiske i rørte vande i fremtiden. Osj og Jalal-Abad er også centre på narkovejen nordover fra Afghanistan, så uden central kontrol med området ventes narkobaronernes indflydelse blot at stige. Islamisters og narkobaroners mulige indtog i konfliktens kerne er noget, som bør stå centralt for en uvildig international undersøgelse.

Flere analytikere har peget på, at tidligere præsident Kurmanbek Bakijevs folk kontrollerede narkohandlen i området. Bag den etniske vold kan således også have været narkobandernes rivalisering om kontrol i magttomrummet efter Bakijev, der blev fordrevet af en voldelige opstand i Bisjkek i april.

Skiftede kirgisiske regeringer har vendt ryggen til volden i syd eller direkte benægtet eksistensen af særlig frugtbar jord for vold. Volden i 2010 lignede meget de blodige etniske sammenstød i området i 1990. Men, som ICG skriver: En afgørende forskel var, at for tyve år siden blev sovjetiske elitestyrker sendt til regionen i seks måneder for at normalisere situationen.

I juni appellerede en meget svag kirgisisk overgangsregering til Moskva om at sende fredsstyrker. Efter nej fra Moskva hævdede samme re- gering, at den selv havde fået kontrol med situationen. Men regeringen har mistet kontrollen over en stor del af landets syd, og borgmesteren i landets sydlige hovedstad Osj, Melis Myrsakmatov, anerkender ikke præsident Rosa Otunbajevas autoritet i området. Blandt farerne for også nabolandene er muligheden for ekstremisternes fremmarch i den konflikts skygge.

Blandt de bedste redskaber til etnisk forsoning er en fælles strategi for genopbygning af nedbrændte kvarterer i Osj og andre sydlige byer. Men borgmester Myrsakmatovs planer for genopbygningen har skabt ny frygt blandt usbekerne og er en åben udfordring for regeringen i Bisjkek. Borgmesteren kalder planen en måde at forhindre ny vold, da han vil flytte folk, så usbekere og kirgisere kommer til at bo dør om dør.

Det så der på overfladen ud til at være god logik i, da volden primært ramte usbekiske og ikke blandede kvarter. Usbekere med nedbrændte huse skal kunne vælge imellem at flytte ind i en boligblok eller til et andet kvarter. Mange usbekere frygtede, at de blot skulle tvinges ind $\mathrm{i}$ små lejligheder. Desuden frygter de at blive splittet og således mere udsatte for ny vold. Begivenhederne i juni viste, at regeringen ikke kunne gøre noget for dem, og de kirgisisk dominerede politistyrker tog i mange tilfælde parti for kirgisiske bander. Da denne skribent besøgte de nedbrændte usbekiske kvarterer i 
Osj, var det et af usbekeres vigtigste argumenter for, at de ville genopbygge deres huse og blive sammen.

\section{Mistroen til 'de andre'}

De monoetniske kvarterer er en del af problemet. Usbekiske familier har traditionelt klumpet sig sammen i delvist lukkede kvarterer uden kontakt til kirgisere. Usbekere i blandede kvarterer er generelt de bedst uddannede. Isolation skaber i sig selv mistro til 'de andre'. To gange før er det gået rigtig galt med hundredvis af døde. Og der kommer givet en fjerde gang, hvis ikke børn og voksne lærer at omgås hinanden i det daglige.

Hvor god en ide det end kan være med flere blandede kvarterer, kan det imidlertid vise sig umuligt uden vold imod århundreders sociale mønstre blandt usbekerne. Præsident Rosa Otunbajeva har gjort klart, at der ikke bliver tale om tvangsforflyttelser, men fra Osj meldes om ringe tillid til, at det løfte holder over for usbekerne. For det var ikke et løfte til dem, kun til internationale donorer. Og de har erfaret, at centralregeringen har ringe magt i byen.

Borgmester Myrsakmatov er kendt som en nær allieret af tidligere præsident Bakijv. Mange kirgisere i Osj støtter stadig Bakijev, mens hovedparten af usbekerne i hvert fald før blodbadet støttede Otunbajeva, så det er også en politisk konflikt, lige som det er en historisk konflikt om den frugtbare jord.

Myrsakmatov har vist sig som en af de farligste fjender af regeringen, når det gælder kontrollen med syd. Otunbajeva har aftalt med OSCE, at organisationen skal sende ubevæbnede politibetjente til syden. Men det har borgmesteren mobiliseret imod. Som udslag af den lokale politiske elites separatisme, har den indsat egne kommandører i sikkerhedsstyrkerne siden volden i juni. Centralregeringen kan hverken besvare udfordringen med vold eller administrativ kontrol, men må bøje sig virkeligheden.

Otunbajeva ser parlamentsvalget 10. oktober som afsæt for et parlamentarisk demokrati, da en ny forfatning afskaffer præsidentens enemagt, men situationen i Osj viser hendes magtesløshed i syd.

Konflikten om genhusning varsler ny vold, der kan undergrave regeringen til fordel for en politisk elite $i$ syd, der ikke viser lyst til at dele magten med hverken regeringen i Bisjkek eller usbekerne omkring dem.

På grund af regeringens uformåen ligger ansvaret for udviklingen hos det internationale samfund.

"Der skete det absurde, at Moskva, der aggressivt har krævet førerrollen i sin centralasiatiske 'zone af privilegerede interesser', forpassede sin chance, selv om rivalerne i regionen, USA og Kina, nok ville have givet Rusland grønt lys til at gribe ind. Barack Obamas regering meldte sig 
først dage efter, at pogromerne var startet, og med ret passive ord. Og Kina der næppe er klar til at tage større ansvar uden for sine grænser, tav", skrev Die Zeit.

Mange kommentatorer har undret sig over, at Rusland, der insisterer på, at Kirgisistan og det øvrige tidligere sovjetiske Centralasien er dets interessesfære, ikke udnyttede chancen for at stadfæste det, da andre store spillere forholdt sig passive.

Men ifølge Die Zeit kunne Rusland ikke gribe ind, "selv om det havde ønsket det". Landets ledelse er underlagt forbud imod at indsætte værnepligtige i udenlandske brændpunkter, og professionelle soldater har det lige så få af som erfaringer i fredsmissioner. Desuden manglede det et internationalt mandat. $\mathrm{Og}$ møllerne i FN's Sikkerhedsråd maler langsomt. Måske var angsten for Usbekistan den vigtigste grund til Ruslands tøven.

\section{Kampen om Manas}

Owen Matthews skrev i Newsweek, at det ikke blot var russisk uformåen, at Rusland kun luftede muligheder for at handle igennem den regionale sikkerhedsorganisation CSTO.

"Rusland spiller nu et smartere spil" ifølge Matthews, der understregede, at militær indgriben let kunne blive "et selvmål, fordi det ville skræmme regionens overvejende totalitære ledere som i Kasakhstan, Usbekistan og Tadsjikistan. Rusland vidste også, at hvis det blev for grådigt i Kirgisistan, ville det sætte en anden nøglefaktor i sin udenrigspolitik på spil: tilnærmelsen til USA".

Indtil for nylig har Rusland søgt at tvinge USA's flybase væk fra Manas ved Bisjkek. "Nu har Kreml opgivet planer om at drive amerikanerne ud af Manas til gengæld for en masse geopolitiske godbidder, herunder afslutning af NATO's parringsleg med tidligere sovjetstater", skrev Matthews og konkluderede: "Takket være denne uskrevne store handel har USA og Rusland nu en fælles interesse i stabilitet i Kirgisistan. Kreml indser, at det afgjort ingen fordele har af at blive suget ned i et etnisk minefelt i det sydlige Kirgisistan, hvor vold imellem etniske grupper er blusset op med jævne mellemrum".

Craig Murray, som Storbritannien trak tilbage som sin ambassadør i Usbekistan i 2004 for - efter Londons mening - for megen kritik af det usbekiske diktatur, skrev i den britiske avis Telegraph: "Kurmanbek Bakijev forblev tæt på USA. Nok for tæt”. Bakijevs søn Maksim blev arresteret i en britisk lufthavn efter en Interpol-efterlysning, "der fokuserede på massive forsyningskontrakter, som Pentagon gav Maksim til USA's base i Kirgisistan. Det synes at være sædvane i Pentagons leg med centralasiatiske diktatorer. I Usbekistan gav Pentagon en enormt profitabel kontrakt til diktatorens datter, Gulnara Karimova, til forsyninger af 
amerikanske baser der". Men diktatoren Islam Karimov smed alligevel amerikanerne ud i 2005.

"Hvor er briterne i alt det her?", spørger Craig Murray: "De etniske konflikter i Usbekistan, Tadsjikistan og Kirgisistan er uadskilleligt forbundne med den primært etniske konflikt i Afghanistan. Men vores politik i Centralasien er ikke andet end støtte til de samme diktatorer, der har forarmet deres lande. Svaret på væksten i islamisk radikalisme er ikke, at rivaliserende store magter støtter regionale diktatorer. Vi har ikke længere råd til kortsigtet politik, bestemt af det presserende behov for logistisk støtte til krigen i Afghanistan".

David Trilling, EurasiaNets redaktør for Centralasien, skrev: "Det internationale samfund har kun tilbudt ringe politisk og sikkerhedsmæssig støtte. Under kampene tiggede de da midlertidige kirgisiske ledere Rusland om militærhjælp. Moskva afviste af angst for regionale reaktioner og viste sig dermed som en svag ven”.

Amerikanerne så til fra deres luftbase uden for Bisjkek - en vital mellemstation for krigen i Afghanistan. Peter Zeihan, leder ved det sikkerhedspolitiske analyseinstitut Stratfor, skrev, at USA's fokus på Mellemøsten "tilbød Rusland en gylden chance for at genetablere sin interessesfære i regionen", i en form, der ligner reminiscenser fra Sovjetunionen.

Siden 2005 har Rusland klart vist sig som dominerende magt i Armenien, Hviderusland, Ukraine, Kasakhstan, Aserbajdsjan, Kirgisistan og Tadsjikistan. Desuden har det intimideret lande som Georgien og Turkmenistan. "På mange måder ligner Kremls strategier i 2010 rigtig meget Katarina den Stores og Josef Stalins strategier i regionen", skrev Stratfors leder, der mener, at Ruslands chance er $n u$, da det af demografiske årsager vil få stadig større vanskeligheder: "Ruslands demografi vil aldrig igen blive så 'positiv' som nu, og det er usandsynligt, at USA's opmærksomhed igen vil blive så afledt som nu".

Rusland må især vogte sig for Centralasiens folkerigeste land, Usbekistan, som er det eneste land i regionen med ressourcer til at engagere sig militært. Det er det eneste land med militærstyrker af et omfang, som Rusland behøver at frygte. Og Usbekistan viger ikke tilbage for at markere, at det ser det meste af tadsjikisk og kirgisisk territorium som retteligen tilhørende Usbekistan. Det gælder den etniske og politiske krudttønde, Fergana Dalen, som er delt imellem de tre lande.

\section{Frygten for Usbekistan}

"I betragtning af alle de midler og motiver, som Usbekistan har, er Moskva ret sikker på, at russiske fredsstyrker til det sydlige Kirgisistan ville fremprovokere en direkte militær konfrontation med et rasende og 
nervøst Usbekistan”, skrev Stratfors Peter Zeihan.

Tasjkent ser nemlig Ruslands forsøg på at drive Vesten ud af Centralasien som optakt til at knægte Usbekistan. Og blandt Usbekistans mange magtmidler er, at det kan afbryde gasleverancer fra Centralasien.

Fjodor Lukjanov, chefredaktør for det russiske tidsskrift Russia in Global Affairs, skrev: "Indtil for nylig synes det tidligere sovjetiske territorium at være en enorm geopolitisk kampplads, hvor store magter kæmpede om de saftigste 'trofæer'. I dag er alt ændret. Næsten alle de store er stødt på økonomiske og politiske problemer på hjemmefronterne. Det har givet Rusland en chance for at vise sit lederpotentiale". Men den russiske analytiker tvivler på, at Moskva er i stand til at udnytte 'de nye muligheder'.

Rusland er sig bevidst, at det vil kræve accept fra de vigtigste naboer Kasakhstan og Usbekistan at gribe ind i Kirgisistan: "Uden det kan russiske styrker ikke bare blive inddraget i borgerkrig, men også i en krig imellem stater", skrev Lukjanov, der således deler frygten for en russisk krig med Usbekistan: "Nu virker det sært at tale om en russisk zone af 'privilegerede interesser'. Om noget er det en 'zone af ansvar'. Hvis Rusland ikke finder svar på udfordringen fra Kirgisistan, vil dets krav om en særlig rolle i regionen være lidet troværdigt. Det er også usandsynligt, at en anden stor magt vil ønske at på- tage sig det tunge ansvar for regionen".

Usbekistans præsident Islam Karimovs var mere tilbageholdende, end han har for vane, da han frygtede, at etnisk uro ville koge over grænsen fra Kirgisistan. En storstilet kampagne skulle holde de etniske følelserne nede, men af frygt for, at det ikke var nok, har landets i forvejen formidable sikkerhedsstyrker fået ekstra ressourcer. Ifølge officielle usbekiske oplysninger er militærudgifterne næsten fordoblet siden 2005.

På usbekisk tv sendes rosenrøde beskrivelser af etnisk harmoni i landet med speakertekster som: "Urolighederne i vore naboterritorier bekymrer vore borgere, men vi skal alle huske, at vi lever i et land, hvor alle borgere er lige og beskyttet af loven. Etniske grupper i vores elskede moderland lever i harmoni".

Beskeden om enhed er også givet af de trykte medier. "Vi kan sige, at tolerance og forståelse imellem de forskellige etniske grupper er symbol på livet i Usbekistan”, skrev Nasriddin Muhammadijev, formand for det Nationale Kulturcenter, en organisation for etniske minoriteter, i avisen Halk Susi.

Der er omkring 130 etniske minoriteter i Usbekistan, men usbekere udgør omkring 80 procent af landets knap 28 millioner indbyggere. De største minoritetsgrupper er russere og folk fra andre centralasiatiske lande. Ifølge lokale observatører vækker usbekisk nationalisme uro blandt minoriteter, især blandt tad- 
sjikere og russere. Tadsjikere, som er i overvægt i byerne Bukhara og Samarkand, klager ifølge EurasiaNet over officiel diskriminering af dem, herunder lukning af tadsjikiske skoler. Og i Samarkand skal tadsjikere sidste år være udrenset fra byens administration.

\section{Mediecensur}

Usbekisk-tadsjikiske spændinger har skabt mindre konfrontationer i Risthan, en lille by i den usbekiske del af Fergana Dalen, samt i Samarkand and Bukuhara. Ifølge lokale observatører har myndighederne forbudt mediedækning af disse episoder. Store plancher på land $\mathrm{og} \mathrm{i}$ by viser regeringens bekymring. "Vort dyrebare moderland tilhører os alle. At sikre dets velfærd og lyse fremtid må være enhver borgers pligt", lyder den enslydende tekst.

Hvert år lanceres den type kampagner, men bidrager ifølge lokale iagttagere ikke til større forståelse.

En intellektuel i Tasjkent siger under betingelse af anonymitet, at regeringens enhedskampagner ikke forholder sig til problemer som usbekisk nationalisme med udelukkelse af minoriteter fra det offentlige liv, som er domineret af usbekisk kultur: "Regeringen fortæller stadig befolkningen, at dette er usbekernes land". Og tilsyneladende tror regimet ikke på sit eget glansbillede, for sikkerhedsstyrkerne tilstedeværelse i Fergana Dalen er øget mar- kant siden volden i den kirgisiske del af Fergana Dalen, som er Centralasiens frugtbareste område og center for islamisk konservatisme, især blandt usbekerne.

Der meldtes om, at regeringen i sommer udstationerede tropper i de vigtigste kirgisisk befolkede landsbyer, øjensynlig for at forhindre lokale usbekiske grupper i hævnangreb for volden mod usbekere i Kirgisistan.

Det hårde diktatur i Usbekistan betyder dog, at myndighederne har lettere ved at holde befolkningen i skak end i Kirgisistan, der altid har været det mest demokratiske hjørne af regionen.

\section{Kluntet diplomati}

Louise Arbour, direktør i International Crisis Group ( ICG), skrev i den britiske avis Independent: "Det internationale samfund har hidtil svaret på volden i Kirgisistan med kluntet diplomati. Mens Rusland og USA holdt sig tilbage, var FN's Sikkerhedsråd, som så ofte før, garant for dette kluntede diplomati”.

Omverdenen slappede af, "da der begyndte at komme rapporter om formindsket kaos. Men den relative ro snyder. Ingen bør undervurdere potentialerne for en ny storstilet etnisk konflikt i hele Fergana Dalen”.

Arbour konkluderede: "Mange vil sige, det er umuligt at forestille sig handling fra et internationalt samfund, der har opmærksomheden bundet andre steder. Men jo længe- 
re tid der går, jo sværere bliver det at udbedre skaderne. For mange er skaden allerede uoprettelig".

Den tidligere italienske diplomat, Carlo Ungaro, der har tilbragt 16 år i Afghanistan som blandt andet politisk rådgiver for de italiensk ledede ISAF styrker i Herat, beskrev til OpenDemocracy Centralasien som en buldrende vulkan:

"Vesten vendte det blinde øje til Centralasiens potentielle katastrofer. De seneste begivenheder i Kirgisistan viser, hvor farlig den holdning er. I nærliggende områder i Afghanistan vil fundet af rige mineralressourcer yderligere komplicere en allerede sprængfarlig situation".

I juni meldte amerikanske medier om fundet af så rige mineralressourcer, at det kan ændre Afghanistans økonomiske udsigter og krigens gang. Det drejer sig blandt andet om kobber, kobolt, guld og lithium.

Mange kan tænkes at kaste sig ind i kampen om Afghanistans rigdomme, så de ikke blot falder i Vestens og især USA's hænder. Russerne har brændt sig varigt i Afghanistan, men har altid set det som del af sin indflydelsessfære, endnu en skygge af det historiske store spil om regionen. Kinesernes officielle ikke-indblanding i Centralasien går hånd i hånd med økonomisk ekspansion $\mathrm{i}$ regionen.

"Ligegyldighed er reelt ikke mulig længere", skrev Ungaro og fremhævede nogle basale kendsgerninger, som må sammenholdes og ana- lyseres grundigt "med både et politisk og et historisk udgangspunkt".

Sovjetunionens sammenbrud skabte mindre ballade og blod i Centralasien, end kunne forventes, bortset fra borgerkrigen i Tadsjikistan. Men faresignalerne var mange i også andre dele af Centralasien.

"Men udenlandske observatører har lullet sig ind i en falsk følelse af sikkerhed. Regimerne har skabt en illusion om nådesløs styrke og varig stabilitet. Den opfattelse dækker imidlertid over en svaghed, der er forværret af tidens gang med en aldrende nomenklatura, der tydeligvis er på vej ud", skrev Ungaro.

Ifølge John Lough fra Chatham House's Russia \& Eurasia Programme udfordrer krisens alvor "den konventionelle visdom om russiske og amerikanske interesser i Centralasien. Man kan hævde, at Rusland kan erkende, at den amerikanske tilstedeværelse i Kirgisistan har en stabiliserende indflydelse og at USA vil hilse russisk lederskab mod krisen velkommen. Det ville vende den accepterede logik om et nulsumsspil af geopolitisk interesser imellem de to i regionen på hovedet".

\section{Farverevolutioner}

Da præsident Bakijev blev styrtet i april i år blev det kaldt endnu en farverevolution, som i Serbien, Georgien, Ukraine og Kirgisistan i første halvdel af 2000'erne. Men forskellen var stor, da udgangspunktet 
for farverevolutionerne var, at store dele af eliten og befolkningen i de pågældende lande afviste at anerkende manipulerede valgresultater. Dengang spillede USA, Europarådet, EU og den offentlige opinion i Vesten en afgørende rolle for de folkelige opstandes succes. Det var ikke tilfældet i Kirgisistan dette forår. Der var ikke nogen valg, som kunne kaldes manipulerede. Det var en folkelig opstand, men det var kupmagerne selv, der ophævede formelt legitime institutioner som parlamentet.

Vestens reaktion viste, at iveren for at gribe aktivt ind, som i høj grad var til stede for Serbien, Georgien og Ukraine, var faldet dramatisk siden. USA og EU er skruet ned i deres egne problemer og ønsket om at sprede demokratiske værdier er falmet drastisk på baggrund af resultaterne af den første bølge af farverevolutioner, hvor tilbageslaget $\mathrm{i}$ ikke mindst Ukraine er til at tage og føle på.

Barack Obamas tale på West Point Militær Akademi er i denne sammenhæng værd at bemærke. Han præsenterede principper for en ny amerikansk sikkerhedsdoktrin. Obama nævnte som en prioritet at støtte demokratiske værdier overalt i verden. Men han understregede, at USA primært skal gøre det ved at stå som et eksempel på respekt for lov og ret og forfatningen og ved at forbedre sit eget demokratiske system. Med andre ord vil Washington ikke knytte sin håb til intervention med det formål at æendre magtforholdene $\mathrm{i}$ andre lande.

Rivaliseringen vil fortsætte i Centralasien, ikke mindst om de rige energiressourcer, men rivaliseringen har markant ændret karakter.

En tid så Vesten Centralasien som et trofæ for sejren i den kolde krig. I den periode udnyttede tidligere sovjetrepublikker ofte muligheder i slaget imellem de store, efter at de havde etableret deres egne stater. Selv de mindste som Kirgisistan skiftede imellem at tækkes USA og Rusland, som da Bakijev fik en stor økonomisk saltvandsindsprøjtning fra Rusland for løftet om at smide den amerikanske base ud og så lod basen blive til en kraftigt forhøjet pris.

Nu er spørgsmålet om de centralasiatiske landes videre udvikling rejst igen, og deres selvstændighed kan vise sig en endnu vanskeligere opgave at sikre, end mens de kunne nyde godt af de stores rivalisering.

Tidligere blev det postsovjetiske Centralasien på grund af dets store energiressourcer set som en 'lækkerbidsken', som før citerede Fjodor Lukjanov har udtrykt det. Nu ses regionen i stadig højere grad som en stor byrde, som mange af landene ikke selv kan bære, mens verdens store enten er uvillige eller ude af stand til det.

Selv Ukraine, et stort og potentielt stærkt europæisk land, har nu næsten ingen anden at søge større økonomisk hjælp fra end Rusland, selv om alle kan se risikoen i en ensidig 
orientering af den store nabo til EU.

Og krisen om Kirgisistan har vist, at når det gælder Centralasien, som er så meget længere væk, har de store skubbet ansvaret for udviklingen fra sig, så realpolitikken kun er dikteret af rivaliseringens logik.

Rusland er optaget af at genetablere 'en zone af privilegerede interesser'. Kina ønsker kun at blande sig gennem ekspansion af Beijings $\varnothing$ konomiske indflydelse. USA har under Obama opgivet den aggressive fremfærd for amerikanske mål og ser alt i regionen igennem de briller, der hedder USA's interesser i Afghanistan.

\section{Begrænset samarbejde}

'Evakueringen' af Kurmanbek Bakijev fra det sydlige Kirgisistan, hvor han barrikaderede sig efter at være fordrevet fra Bisjkek, var et eksempel på russisk-amerikansk samarbejde. En ny forståelse om begge at beholde militærbaser i Kirgisistan er i hvert fald for nærværende et andet eksempel. Men længere er det heller ikke gået. I princippet skulle en nøglerolle for at dæmpe konflikter som i Kirgisistan tilfalde den regionale samarbejdsorganisation Den Kollektive Sikkerhedstraktat Organisation (CSTO). Internationalt engagement i en konflikt er nu engang mere overbevisende, når der er en militær komponent.

Men her gælder spændingerne også internt i CSTO, da ikke mindst Usbekistan var dybt foruroliget over, at Rusland for første gang aktivt støttede regimeændring i et naboland med støtte til oppositionen både før og efter Bakijevs fald. Og Hviderusland gik åbent imod Rusland i den sag, da det insisterede på Bakijevs legitimitet og nu huser ham.

For første gang er den vigtigste politiske barriere for Ruslands handlinger i regionen ikke bestemt af USA og dets vestlige allierede eller af Kina. Den største barriere er de komplekse interesser hos tidligere sovjetrepublikker i regionen.

Kirgisistan er en lilleput i den sammenhæng. Den vigtigste barriere for Rusland er den folkerige militærmagt Usbekistan med også Kasakhstan og Tadsjikistan med i spillet.

Og volden i Kirgisistan viste, at de tidligere sovjetrepublikker i Centralasien er vulkaner, der engang sov men nu buldrer i deres indre. Balladen i Kirgisistan kan derfor ikke ses som en isoleret episode. Det er en del af et generelt dybt foruroligende billede.

Vibeke Sperling er Østeuropakorrespondent ved dagbladet Politiken og redaktør af Udenrigs. 